\title{
Development and optimization of a digestion method for heavy metal determination in scleractinian corals by Atomic Absorption Spectrometry (AAS)
}

\section{Desarrollo y optimización de un método de digestión para la determinación de metales pesados en corales escleractíneos por Espectrometría de Absorción Atómica (EAA)}

\author{
M.D. Galindo-Riaño ${ }^{1 *}$ \\ L. Castellón ${ }^{1}$ \\ K. González² \\ M. García-Vargas ${ }^{1}$ \\ ${ }^{1}$ Departamento de Química Analítica \\ Facultad de Ciencias \\ Universidad de Cádiz \\ 11510 Puerto Real, Cádiz, España \\ *E-mail: dolores.galindo@uca.es \\ ${ }^{2}$ Instituto Superior de Ciencias y Tecnología Nucleares \\ Ave. Salvador Allende Esq. Luaces \\ Quinta de los Molinos, Plaza \\ Ciudad de La Habana, Cuba
}

Recibido en noviembre de 2000; aceptado en septiembre de 2002

\begin{abstract}
In the last decade a great number of studies have been directed especially to the evaluation of the environmental impact of heavy metal concentration levels in coral barriers. Related to studies in scleractinian corals, many chemical techniques have been proposed to determine heavy metals but Atomic Absorption Spectrometry (AAS) is the most widely used; however, regarding sample pretreatment methods there is not a unique criterion on the requirements to obtain the precise and accurate results needed in this analysis. So, in this paper the application of several widely used pretreatment methods for digestion of corals and sediments were studied in which $\mathrm{HNO}_{3}, \mathrm{HCl}$ and $\mathrm{HClO}_{4}$ are used in different conditions (concentration, temperature, etc.), with the aim of comparing their efficiency. The method in which a combination of $\mathrm{HNO}_{3}$ and $\mathrm{HClO}_{4}$ was used resulted the most effective one. A $2^{2}$ experimental design was carried out to study the influence of the $\mathrm{HNO}_{3}$ volume as well as to optimize the $\mathrm{HNO}_{3}: \mathrm{HClO}_{4}$ mixture. Finally the method was validated using reference certificate material (SOIL-7) using the NIST accuracy test and applying it in the analyses of different coral samples which produced results with appropriate analytical quality.
\end{abstract}

Key words: sample pretreatment, scleractinian coral, heavy metal, marine pollution.

\section{Resumen}

En la última década un gran número de estudios se han enfocado especialmente a la evaluación del impacto ambiental de los niveles de concentración de metales pesados en las barreras coralinas. En relación al estudio de metales pesados en corales escleractíneos, la técnica de análisis más utilizada ha sido la Espectrometría de Absorción Atómica (EAA); sin embargo, en cuanto al pretratamiento químico de digestión de las muestras no existe un criterio único sobre el método más adecuado que proporcione los resultados con la precisión y exactitud requeridos en este tipo de análisis. Por ello en este trabajo se estudia la aplicación de algunos de los tratamientos más utilizados en la digestión de corales y sedimentos, mediante el empleo de $\mathrm{HNO}_{3}$,

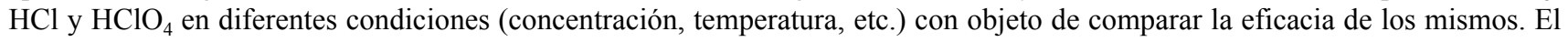
método de disolución de la muestra con $\mathrm{HNO}_{3}$ y $\mathrm{HClO}_{4}$ resultó ser el más adecuado. Para realizar la optimización de dicho tratamiento se realizó un diseño experimental $2^{2}$ con el fin de estudiar la influencia del volumen de $\mathrm{HNO}_{3}$, así como el sinergismo de la mezcla $\mathrm{HNO}_{3}: \mathrm{HClO}_{4}$. Finalmente, el método fue validado con la utilización de material de referencia certificado (SOIL-7), utilizando el test de exactitud NIST que es aplicado al análisis de diferentes muestras de corales obteniendo resultados con la calidad analítica adecuada.

Palabras clave: pretratamiento de la muestra, corales escleractíneos, metales pesados, contaminación marina. 


\section{Introduction}

Coral reefs are biological communities born in the marine floor consisting of a solid structure of calcareous stone constituted by $\mathrm{CaCO}_{3}$. Their major constituents are corals which are characterized by a low resistance to human impacts and slow recovery rates.

The incorporation of heavy metals in the coralline skeleton is dealt in biological and physiological studies that interpret the analysis of their metal concentrations considering two fundamental incorporation routes: first, the incorporation of dissolved metals in the system into the aragonite structure of the calcareous skeleton; and second, the incorporation by adsorption as particulate or suspended material (Howrad and Brown, 1984; Barnes and Chalker, 1990).

Scleractinian corals are so important in the reef development that they can also be considered, according to many authors, as indicative of heavy metal pollution levels in marine ecosystems. Therefore, when heavy metal pollution assesments are required, in first place it is necessary to count on an analytical tool that allows to establish their total content in this kind of samples. Is in this field that the application of the Atomic Absorption Spectrometry (AAS; Price, 1979) to studies related to the environment has found their wider and most diversified repercussion. The AAS is an analytical technique able to determine the immense majority of elements of ecological interest, as heavy metals. Heavy metals feature two characteristics that make them highly dangerous: first, they can not be eliminated from the environment by natural processes and, second, because through complex processes they can even get incorporated into the nutritional chains, being able to indirectly affect humans.

Concentrations of these elements of environmental interest can fluctuate within a wide interval from $\mathrm{mg} \mathrm{kg}^{-1}$ to $\mathrm{ng} \mathrm{k}^{-1}$ or $n g \mathrm{~L}^{-1}$, depending on the element and the sample studied. It is therefore an attribution of the analysts to evaluate which of the different analytical procedures available to employ, in order to select a method that combines the best sensibility, precision and accuracy requirements (Valcárcel and Ríos, 1992).

The use of AAS combines the high selectivity of the spectral atomic methods with the use of wet methods that oftenly require a previous digestion step in which solid or liquid samples with suspensed material are converted into an homogeneous liquid phase; therefore, during the chemical digestion or dissolution it is important for the sample to be completely dissolved and, thus, the most adequate solvent and the simplest procedure must be used.

The wide variety of acid digestion methods, or acid extractions, can be classified, according to their strength, in: total, strong, moderate and weak. Total treatments release all the metal present in the sample but imply the use of HF. Thus, many analysts prefer using $\mathrm{HNO}_{3}, \mathrm{HCl}, \mathrm{HClO}_{4}$ and $\mathrm{H}_{2} \mathrm{SO}_{4}$, separatedly, or in different combinations and conditions (concentration, temperature, etc), attaining different digestion efficacies.

\section{Introducción}

Un arrecife coralino es una comunidad biológica que nace en el suelo marino y que consta de una estructura sólida de piedra caliza constituida por $\mathrm{CaCO}_{3}$. Sus principales constituyentes son los corales, los cuales se caracterizan por presentar una baja resistencia al impacto humano y lentas tasas de recuperación.

La incorporación de metales pesados en el tejido coralino es tratada en estudios biológicos que interpretan el análisis de las concentraciones de metales en los corales teniendo en cuenta dos vías de incorporación fundamentales: primero, las inclusiones estructurales de metales disueltos en el sistema a la estructura de aragonita de su exoesqueleto calcáreo; y segundo, las inclusiones por adsorción como material particulado o en suspensión (Howrad y Brown, 1984; Barnes y Chalker, 1990)

Los corales escleractíneos, además de ser muy importantes en el desarrollo de un arrecife, pueden ser considerados como indicadores de los niveles de contaminación por metales pesados en los ecosistemas marinos. Cuando se destaca la necesidad de una evaluación de la contaminación por metales pesados, en primer lugar, es necesario poseer una herramienta analítica que permita establecer los contenidos totales en este tipo de muestras. En esta tarea, la aplicación de la Espectrometría de Absorción Atómica (EAA) (Price, 1979) a estudios relacionados con el medio ambiente ha encontrado su más amplias y variadas repercusiones. La EAA es una técnica analítica capaz de determinar la inmensa mayoría de los elementos de interés ecológico, como es el caso de los metales pesados. Estos elementos son altamente peligrosos por dos características, en primer lugar, porque no pueden ser eliminados del medio ambiente por medio de procesos naturales y, en segundo lugar, porque a través de procesos complejos pueden llegar a incorporarse a las cadenas alimenticias, pudiendo afectar indirectamente al hombre.

Las concentraciones en las que se pueden encontrar estos elementos de interés ambiental, fluctúan dentro de un amplio intervalo que abarca desde $\mathrm{mg} \mathrm{kg}^{-1}$ hasta $\mathrm{ng} \mathrm{kg}^{-1}$ ó $\mathrm{ng} \mathrm{L}^{-1}$, dependiendo del elemento y la muestra en cuestión. Por ello es función de los analistas el valorar los diferentes procedimientos analíticos disponibles y técnicas a emplear, con el fin de seleccionar el método que combine los mejores requerimientos de sensibilidad, precisión y exactitud (Valcárcel y Ríos, 1992).

La aplicación de la EAA combina la alta selectividad de los métodos atómicos espectrales con la necesaria aplicación de métodos húmedos, ya que es frecuente utilizar una etapa previa de digestión donde las muestras sólidas o líquidas con partículas en suspensión son llevadas a una fase líquida homogénea. Por este motivo, durante el ataque químico o disolución de la muestra es importante que ésta se disuelva completamente y para ello debe utilizarse el método más adecuado y sencillo.

Los métodos de digestión o disolución pueden clasificarse en cuatro grandes grupos según la fuerza del ataque: total, fuerte, moderado ó débil. El ataque total libera todo el metal presente en la muestra pero implica el uso de HF, por lo que 
Several comparative studies and international intercalibration exercises (OIEA, 1985; 1987) show contradictory results regarding the acid digestion methods in coral samples. This results consider the $\mathrm{HNO}_{3}: \mathrm{HCl}$ mixture as the most widely used method and its strong digestion comparable to total digestion. In relation to organism digestions two opposing criteria exist in relation to the $\mathrm{HClO}_{4}$ use, some opposing it, due to the explosion risk, and some other promoting it because of its organic matter dehydrating capacity. Some other authors use this acid mainly with $\mathrm{HNO}_{3}$, since this way its dehydrating capacities are decreased, avoiding such explosive reactions and increasing the oxidizing properties of the mixture (González, 1989).

In a pollution study carried out at the marine station in Moa Bay, Cuba, coral samples were subjected to digestion using a mixture of concentrated $\mathrm{HNO}_{3}$ and concentrated $\mathrm{HCl}$, and the $\mathrm{Co}, \mathrm{Cu}, \mathrm{Fe}, \mathrm{Mn}, \mathrm{Ni}$, and $\mathrm{Zn}$ contents were quantified by AAS, yielding results that can be reproduced consistently, but their accuracy was not specified (Martínez et al., 1989).

In works carried out in the Great Barrier Reef, a variety of octocorals and scleractinian corals were collected to determine their metal concentrations. The octocorals samples were digested using concentrated $\mathrm{HNO}_{3}$ and a $1: 1$ mixture of $\mathrm{HNO}_{3}: \mathrm{HClO}_{4}$. The scleractinian coral samples were previously subjected to an extraction and concentration process in order to separate the trace elements from the $\mathrm{Ca}$ matrix interference. The samples were digested with $20 \mathrm{~mL}$ of $\mathrm{HNO}_{3}\left(1 \mathrm{~mol} \mathrm{~L}^{-1}\right)$, and the $\mathrm{pH}$ was adjusted between 4 and 5 with $\mathrm{NH}_{4} \mathrm{OH}$ and/or $\mathrm{HNO}_{3}$ solution. The extraction was carried out with APDC and AMK. In this study, heavy metals as $\mathrm{Zn}, \mathrm{Cu}, \mathrm{Cd}, \mathrm{Ni}$ and $\mathrm{Pb}$ were determined (Denton and Burdon-Jones, 1986). These proposed methods are seldom used since they are technically hard procedures requiring a lot of time ( 72 hours) and there are no criteria regarding their accuracy.

Another kind of digestion was used in studies carried out on corals from the Galapagos Islands. The samples were dissolved in $\mathrm{HNO}_{3}\left(2 \mathrm{~mol} \mathrm{~L}^{-1}\right)$ and trace metals were separated by co-precipitation using Co as a collector and APDC (Shen and Boyle, 1988) as a complex agent. This procedure isolated the trace metals from the calcareous matrix facilitating their graphite-oven analysis.

Other authors have used a combination of $\mathrm{HNO}_{3}$ and $\mathrm{H}_{2} \mathrm{O}_{2}$ for digestion, preparing the calibration curve standards with $\mathrm{CaCO}_{3}$, in order to correct possible $\mathrm{Ca}$ interferences (Glynn, 1989) and to achieve an easy sample manipulation.

Finally, considering the chemical treatment of the coral samples, it can be deduced that there is not a unique criterion to treat the samples and, among the digestion methods used, there are no data regarding their efficiency and/or accuracy and whether the total digestion can be or not substituted by them (Schneider and Smith, 1982; Brown, 1987; Linn et al., 1990; Luoma, 1990; Hanna and Muir, 1990; D’Elia et al., 1991; Páez-Osuna and Ruíz Fernández, 1995; Esslemont, 1997).

In order to obtain good quality analytical results and, therefore achieve a correct evaluation of the heavy metal muchos prefieren como alternativa el empleo de $\mathrm{HNO}_{3}, \mathrm{HCl}$, $\mathrm{HClO}_{4} \mathrm{y} \mathrm{H}_{2} \mathrm{SO}_{4}$ por separado, o en diferentes combinaciones y condiciones de digestión, logrando diferente efectividad en el ataque.

Diversos estudios comparativos y ejercicios de intercalibración internacionales (OIEA, 1985; 1987) arrojan resultados contradictorios en cuanto a los métodos de digestión ácida utilizados para muestras de corales. Éstos suelen considerar la mezcla $\mathrm{HNO}_{3}: \mathrm{HCl}$ como la más empleada y sus fuertes ataques comparables con el ataque total. Con relación a la digestión de muestras de organismos, existen dos criterios en oposición con relación al uso del $\mathrm{HClO}_{4}$ : los que se oponen a su uso, debido a los riesgos de explosión, y los que lo favorecen debido a sus características deshidratantes sobre la materia orgánica. Otros autores suelen emplear este ácido junto con $\mathrm{HNO}_{3}$ ya que éste disminuye su capacidad higroscópica, evitando reacciones violentas e incrementando las propiedades oxidantes de la mezcla (González, 1989).

En un estudio de contaminación realizado en la plataforma marina de la Bahía de Moa, Cuba, las muestras de corales se sometieron a digestión con una mezcla de $\mathrm{HNO}_{3 \text { conc. }}: \mathrm{HCl}_{\text {conc., }}$, cuantificándose los contenidos de $\mathrm{Co}, \mathrm{Cu}, \mathrm{Fe}, \mathrm{Mn}$, Ni y Zn por EAA, y obteniéndose resultados con buena reproducibilidad; sin embargo, no se especifica el grado de exactitud de éstos (Martínez et al., 1989).

En trabajos realizados en la Gran Barrera Coralina, una variedad de octocorales y corales escleractíneos fueron muestreados para cuantificar sus contenidos metálicos. Las muestras fueron digeridas utilizando ácido $\mathrm{HNO}_{3}$ conc. y la mezcla 1:1 de $\mathrm{HNO}_{3}: \mathrm{HClO}_{4}$. Las muestras de corales escleractíneos fueron sometidas a un proceso de extracción previo al análisis final, con el objetivo de separar los elementos trazas de la matriz de calcio interferente. Las muestras fueron disueltas en $20 \mathrm{~mL}$ de $\mathrm{HNO}_{3} 1 \mathrm{~mol} \mathrm{~L}^{-1}$, se ajustó el $\mathrm{pH}$ entre 4 y 5 con disolucion de $\mathrm{NH}_{4} \mathrm{OH}$ y/o $\mathrm{HNO}_{3}$ diluido. La extracción fue realizada con APDC y AMK. En este estudio, entre otros, fueron determinados metales pesados como $\mathrm{Zn}, \mathrm{Cu}, \mathrm{Cd}$, $\mathrm{Ni}$ y $\mathrm{Pb}$ (Denton y Burdon-Jones, 1986). Los métodos propuestos en este trabajo son poco utilizados, pues resultan ser procedimientos laboriosos debido al tiempo que consumen $(72 \mathrm{~h})$ y a la manipulación; además, no existe ningún criterio acerca de su exactitud.

En estudios realizados en corales de las Islas Galápagos se aplicó otra forma de digestión. Las muestras fueron disueltas con $\mathrm{HNO}_{3}\left(2 \mathrm{~mol} \mathrm{~L}^{-1}\right)$ y los metales trazas fueron separados por coprecipitación usando Co como colector y APDC como agente complejante (Shen y Boyle, 1988). Este procedimiento aislaba los metales de interés de la matriz de calcio para facilitar su análisis en horno de grafito.

Otros autores han empleado para la digestión una combinación de $\mathrm{HNO}_{3}$ y $\mathrm{H}_{2} \mathrm{O}_{2}$, preparando los patrones de la curva de calibrado con $\mathrm{CaCO}_{3}$ para corregir posibles interferencias del Ca (Glynn, 1989) y reduciendo de esta forma la manipulación de la muestra. 
concentration levels and their environmental impact to the marine ecosystem we proposed the selection of the most reliable procedure among the most widely used and simple methods, to find the most suitable experimental conditions and those that generate the most accurate and precise results in coral samples.

\section{Material and methods}

With the aim to establish a methodology for the determination of heavy metals in scleractinian corals, the influence of the previous treatment to the sample in the quality of the results was studied, emphasizing the need to quantify the actual and total value of the metal concentrations with the smallest variability.

Treatments are based on the use of $\mathrm{HNO}_{3}$ with different proportions and concentrations, as well as its combined effect with $\mathrm{HCl}$ and $\mathrm{HClO}_{4}$.

Among the characteristics of $\mathrm{HNO}_{3}$ that make it the most widely used are its strength, extreme corrosiveness, oxidizing power and its inability to form insoluble salts with any metal.

Since the use of $\mathrm{H}_{2} \mathrm{SO}_{4}$ would not have allowed the sample to totally dissolve due to the matrix $\left(\mathrm{CaCO}_{3}\right)$ precipitation with some of the metals of interest (such as $\mathrm{Pb}$ ), it was not used.

\section{Collection and preparation of samples}

For this study Colpophyllia natans was selected during all the methodological process and the methology developed was applied to Dichocoemia stokesi, Porites porites, Porites astreoides and Micetophyllia lamarkiana, all of them scleractinian corals of the Cuban insular platform.

Corals were taken by autonomous diving at depths of 5 and $10 \mathrm{~m}$ in the Jaimanitas zone coastal reef, north of the City of Havana (Cuba). They remained in freshwater for 72 hours and then were cleaned with abundant water with pressure and sunk in nitric acid (1\%), where they were preserved for 24 hours. All this process guarantees all organic matter to be eliminated from the coral surface, just remaining the calcareous skeleton. Finally they are cleaned with abundant distilled water and dried in a heater at $105^{\circ} \mathrm{C}$ during 24 hours (González, 1989).

The specimens were sectioned with a diamond-top saw in $\sim 5$-mm thick. They were cleaned with HNO3 (1\%) and distilled water to eliminate possible superficial pollution and dried again in a heater at $105^{\circ} \mathrm{C}$. Samples were pulverized during 15 min in an automatic agate mortar, after a previous crushing in a porcelain mortar, until obtaining a fine homogeneous powder with a grain size of 50-100 $\mu \mathrm{m}$ (Gómez et al., 1995).

Finally the samples were wrapped in vegetable paper envelopes and put in a drier until their processing.

\section{Digestion methods}

Four different types of digestions were used in 1-g samples. The samples were dissolved by triplicate, with two blank
Finalmente, con relación al tratamiento químico realizado a las muestras de corales se puede concluir que no existe un criterio único para su tratamiento $y$, acerca de las metodologías utilizadas, no existen datos concretos acerca de su eficacia y/o exactitud y de si el ataque total puede ser reemplazado por estos métodos de digestión (Schneider y Smith, 1982; Brown, 1987; Linn et al., 1990; Luoma, 1990; Hanna y Muir, 1990; D’Elia et al., 1991; Páez-Osuna y Ruíz-Fernández, 1995; Esslemont, 1997).

Con objeto de obtener resultados analíticos adecuados y poder evaluar correctamente los niveles de concentración de metales pesados y su impacto en los ecosistemas marinos, en este trabajo se propone seleccionar, de entre algunos de los métodos más utilizados y sencillos, el procedimiento analítico más adecuado, encontrando las condiciones experimentales óptimas del método que se seleccione y que generen resultados con la mayor precisión y exactitud para muestras de corales.

\section{Materiales y métodos}

Con el objetivo de establecer una metodología para la determinación de metales pesados en corales escleractíneos, se estudió la influencia del tratamiento previo a la muestra sobre la calidad de los resultados, enfatizando la necesidad de cuantificar el valor total y real de la concentración de metales pesados con la menor variabilidad.

Los tratamientos estudiados se basan en la utilización de $\mathrm{HNO}_{3}$ en diferentes proporciones y concentraciones, así como su combinación con $\mathrm{HCl}$ y $\mathrm{HClO}_{4}$.

Entre las características más importantes que favorecen la utilización del $\mathrm{HNO}_{3}$ destacan el ser un ácido muy fuerte, sumamente corrosivo, oxidante eficaz y que no forma sales insolubles con ningún metal.

En nuestro estudio no se utilizó $\mathrm{H}_{2} \mathrm{SO}_{4}$ dado que su aplicación no permitiría la disolución total de la muestra por la precipitación de la matriz $\left(\mathrm{CaCO}_{3}\right) \mathrm{y}$, con ella, la coprecipitación de algunos metales de interés ambiental tales como $\mathrm{Pb}$.

Toma y preparación de muestras

Para este estudio se seleccionó la especie Colpophyllia natans y la metodología desarrollada fue aplicada también a las especies Dichocoemia stokesi, Porites porites, Porites astreoides y Micetophyllia lamarkiana, diferentes tipos de corales escleractíneos de la plataforma insular cubana.

Los corales fueron recolectados por buceo autónomo a profundidades de 5 y $10 \mathrm{~m}$ en el arrecife costero de la zona de Jaimanitas del litoral norte de la Ciudad de La Habana (Cuba). Se mantuvieron en agua dulce durante 72 horas, luego se lavaron con abundante agua a presión y fueron colocados en ácido nítrico (1\%), en el que se conservaron por 24 horas. Todo este proceso garantiza la eliminación de los restos de materia orgánica de la superficie del coral, quedando solamente el exoesqueleto calcáreo. Finalmente se lavaron con abundante agua destilada y fueron secados en estufa a $105^{\circ} \mathrm{C}$ durante 24 horas (González, 1989). 
solutions for each method. Each portion was measured three times and the statistic processing of the results was performed with the Babxel (1995) software.

The heavy metal concentrations in the dissolved samples were measured in an atomic absorption spectrometer Unicam model 929 Solaar System coupled to a PC for the control of the equipment and the acquisition of data, using for all cases airacetylene flame and deuterium lamp background correction.

The calibration curves were prepared for the acid concentration in samples and standards to remain constant. For the $\mathrm{Fe}$ determination, the compensation adjustment to the calibration curve was used, adding to standards a $35 \%$ of $\mathrm{Ca}$ to offset the matrix effect (Brown, 1987; Shen et al., 1987).

\section{Digestion I (weak)}

In a $250-\mathrm{ml}$ polyethylene (PE) screw-top bottle, $25 \mathrm{~mL}$ of 8 mol L-1 $\mathrm{HNO}_{3}$ were added to a 1 -gr sample, with stirring, and put all together in a $90^{\circ} \mathrm{C}$ hot water bath during $30 \mathrm{~min}$. The resulting disolution was then filtered cold using Whatman 41 filter paper and poured into a $25-\mathrm{mL}$ volumetric flask, where it was finally leveled up with $1 \% \mathrm{HNO}_{3}$ (Carmody et al., 1983).

\section{Digestion II (strong)}

This treatment was based on the use of $\mathrm{HNO}_{3}$ conc. and $\mathrm{HCl}$ conc.; 1 gram of sample was put into a $250-\mathrm{mL}$ Erlenmeyer glass flask with $25 \mathrm{~mL}$ of deionized water. Shaking the emulsion, $1 \mathrm{~mL}$ of $\mathrm{HNO}_{3}$ conc. and $10 \mathrm{~mL}$ of $\mathrm{HCl}$ conc. were added, heating the solution with reflux for 3 hours in a heating plate at $100^{\circ} \mathrm{C}$ until almost dry. The filtered solution was poured into a $25-\mathrm{mL}$ volumetric flask where it was finally leveled up with $1 \% \mathrm{HNO}_{3}$ (Martínez et al., 1989).

\section{Digestion III (strong)}

This treatment was considered a strong one since it was based on the use of concentrated $65 \% \mathrm{HNO}_{3}$ : One gram of sample was put into a 250 -mL Erlenmeyer glass flask to which $3 \mathrm{~mL}$ of concentrated $\mathrm{HNO}_{3}$ were added slowly, drop by drop, with stirring. The solution was almost dried in a heating plate at $100^{\circ} \mathrm{C}$ for 1 hour. After cooling it down, $1 \mathrm{~mL}$ of acid was added, drying again the solution with the same procedure. This operation was repeated until completing $6 \mathrm{~mL}$ of $\mathrm{HNO}_{3}$ conc. Finally the residues were rinsed with $10 \mathrm{~mL}$ of deionized water, the solution left to cool and vacuum-filtered, and finally poured into a $25-\mathrm{mL}$ volumetric flask, where it was leveled up with deionized water (Shen et al., 1987).

\section{Digestion IV (strong)}

The strong digestion was carried out with concentrated $\mathrm{HNO}_{3}$ and $\mathrm{HClO}_{4}$ : A mixture $\mathrm{HNO}_{3}: \mathrm{HClO}_{4}(4: 2)$ was added to 1 gram of sample in a $250-\mathrm{mL}$ Erlenmeyer glass flask, heating with reflux during 1 hour at $95^{\circ} \mathrm{C}$, until the sample was almost
Las especies se seccionaron con una sierra de punta de diamante en lascas de aproximadamente $5 \mathrm{~mm}$ de espesor. Se lavaron con $\mathrm{HNO}_{3}(1 \%)$ y agua destilada para de esta forma eliminar posibles contaminaciones superficiales, se secaron de nuevo en estufa a $105^{\circ} \mathrm{C}$. Luego se les realizó una trituración previa en un mortero de porcelana de manera que posteriormente se pudiese triturar la muestra en el mortero de ágata automático. Las muestras se pulverizaron durante $15 \mathrm{~min}$, obteniéndose un polvo fino homogéneo, con tamaño de grano entre 50 y $100 \mu \mathrm{m}$ (Gómez et al., 1995).

Finalmente las muestras fueron empacadas en sobres de papel vegetal y colocadas en una secadora hasta su ulterior procesamiento.

\section{Métodos de digestión}

Se aplicaron cuatro tipos de digestión diferentes para $1 \mathrm{~g}$ de muestra. Las muestras fueron tratadas por triplicado, con la preparación de dos disoluciones blancos para cada método. Cada muestra digerida fue medida tres veces y el tratamiento estadístico de los resultados se realizó con el software Babxel (1995).

Las mediciones se realizaron en un espectrómetro de absorción atómica, modelo Unicam 929 Solaar System, acoplado a un PC para el control del equipo y la adquisición de datos, utilizando para todos los casos la llama de aire-acetileno y corrección de fondo con lámpara de deuterio.

Las curvas de calibración fueron preparadas de manera que se mantuviera constante la naturaleza y concentración ácida en muestras y patrones. Para la determinación de Fe se empleó el ajuste de compensación de la curva de calibración, adicionando a los patrones un $35 \%$ de calcio, para contrarrestar el efecto matriz (Brown, 1987; Shen et al., 1987).

\section{Digestión I (débil)}

Se puso un gramo de muestra en un recipiente de polietileno (PE) de $250 \mathrm{~mL}$, con tapa. Posteriormente se le añadieron $25 \mathrm{~mL}$ de $\mathrm{HNO}_{3} 8 \mathrm{~mol} \mathrm{~L}^{-1}$ con agitación, colocándose en un baño de agua caliente a $90^{\circ} \mathrm{C}$ durante $30 \mathrm{~min}$. Posteriormente la disolución se filtró en frío utilizando papel de filtro Whatman 41. La disolución filtrada se trasvasó a un matraz de $25 \mathrm{~mL}$, donde finalmente se enrasó con $\mathrm{HNO}_{3}$ al $1 \%$ (Carmody et al., 1983).

\section{Digestión II (fuerte)}

Esta digestión se basa en la utilización de $\mathrm{HNO}_{3}$ conc. y $\mathrm{HCl}$ conc..En un Erlenmeyer de $250 \mathrm{~mL}$ se añadieron $25 \mathrm{~mL}$ de agua desionizada a un gramo de muestra y se agitó la suspensión adicionándose $1 \mathrm{~mL}$ de $\mathrm{HNO}_{3}$ conc. y $10 \mathrm{~mL}$ de $\mathrm{HCl}$ conc. La disolución se secó casi totalmente usando una placa calefactora a $100^{\circ} \mathrm{C}$ durante 3 horas con reflujo. La disolución fue filtrada y trasvasada a un matraz de $25 \mathrm{~mL}$ donde se enrasó con $\mathrm{HNO}_{3}$ al 1\% (Martínez et al., 1989). 
dry. Afterwards, this was cooled down and, then, $10 \mathrm{~mL}$ of concentrated $\mathrm{HNO}_{3}$ were added, heating again to almost total dryness with reflux during 2 hours at $115^{\circ} \mathrm{C}$. Finally, the sample was rinsed with $10 \mathrm{~mL}$ of deionized water, cooled down and filtered, and the filtered solution was poured into a $25-\mathrm{mL}$ volumetric flask, where it was leveled up with deionized water (Denton and Burdon-Jones, 1986).

\section{Results and discussion}

In order to study the significant differences among the digestion methods, the elements $\mathrm{Fe}, \mathrm{Cu}$ and $\mathrm{Zn}$ were selected. These metals were selected since, in previous analyses, $\mathrm{Fe}$ was the most abundant element after $\mathrm{Ca}$, and it is representative of the elements whose measurements are affected by the calcium matrix effect when using air-acetylene flame, meanwhile $\mathrm{Zn}$ and $\mathrm{Cu}$ are elements not showing interferences by the matrix effect. The results obtained from using of the four different digestion methods are shown in table 1.

From these results we performed a mean's comparison test, based on the $t$-Student criterion, where our null hypothesis, $\left[\mathrm{H}_{0}\right]: \bar{x}_{1}=\bar{x}_{2}$, consisted on proving whether there are or not significant differences among the concentration values obtained by means of the different treatments and, as an alternative hypothesis $\left[\mathrm{H}_{1}\right]: \bar{x}_{1} \neq \bar{x}_{2}$ and, in this case, if $\bar{x}_{1}>\bar{x}_{2}$, then $\bar{x}_{1}$ is the value accepted as truth, and the method used is the procedure capable of extracting the greatest concentration of the coralline matrix.

From the Student's $t$-test significant statistical differences among the digestion methods used were found at $95 \%$ level, and digestion IV using $\mathrm{HNO}_{3}: \mathrm{HClO}_{4}$ turned out to be the most efficient procedure for dissolving the samples.

\section{Experimental Design $2^{2}$}

In order to characterize the parameters of the digestion IV procedure, chosen as the best, an experimental design $2^{2}$ was used to obtain a mathematical model for this dissolution process, in a zone determined by a factorial space.

In this system, the influence of different synergic mixtures of $\mathrm{HNO}_{3}: \mathrm{HClO}_{4}$ and the volume of $\mathrm{HNO}_{3}$ in the second step

\section{Digestión III (fuerte)}

Este procedimiento de ataque fuerte se basa en el uso de $\mathrm{HNO}_{3}$ concentrado al $65 \%$. Se colocó un gramo de muestra en un Erlenmeyer de $250 \mathrm{~mL}$ al que se añadieron lentamente, gota a gota y con agitación, $3 \mathrm{~mL}$ de $\mathrm{HNO}_{3}$ conc. La disolución se llevó casi a sequedad en una placa calefactora a $100^{\circ} \mathrm{C}$ durante 1 hora. Posteriormente se enfrío y se adicionó $1 \mathrm{~mL}$ más de ácido, llevando nuevamente la disolución casi a sequedad por medio del mismo procedimiento. Esta operación se repitó hasta completar $6 \mathrm{~mL}$ de $\mathrm{HNO}_{3}$ conc. Los residuos se arrastraron con $10 \mathrm{~mL}$ de agua desionizada, la disolución se enfrió y se filtró al vacío, y finalmente se trasvasó a un matraz de $25 \mathrm{~mL}$ donde se enrasó con agua desionizada (Shen et al., 1987).

\section{Digestión IV (fuerte)}

Se aplicó la digestión fuerte basada en el empleo de $\mathrm{HNO}_{3}$ y $\mathrm{HClO}_{4}$ concentrados. A un gramo de muestra en un erlenmeyer de $250 \mathrm{~mL}$, se añadió la mezcla $\mathrm{HNO}_{3}: \mathrm{HClO}_{4}$ en proporción 4:2, llevando casi a sequedad a reflujo durante 1 hora a $95^{\circ} \mathrm{C}$. Posteriormente se dejó enfriar y se añadieron 10 $\mathrm{mL}$ de $\mathrm{HNO}_{3}$ concentrado, volviendo a llevar casi a sequedad con reflujo, durante 2 horas a $115^{\circ} \mathrm{C}$. Finalmente, los residuos fueron arrastrados con $10 \mathrm{~mL}$ de agua desionizada, la disolución se enfrío, se filtró y se trasvasó a un matraz de 25 $\mathrm{mL}$, donde se enrasó con agua desionizada (Denton y BurdonJones, 1986).

\section{Resultados y discusión}

Para estudiar las diferencias significativas entre los métodos de digestión se seleccionaron los elementos $\mathrm{Fe}, \mathrm{Cu}$ y $\mathrm{Zn}$ debido a que, en análisis previos, el Fe fue el más abundante después del Ca y es representativo de aquellos elementos cuya medición se ve afectada por el efecto de la matriz de calcio en la llama de aire-acetileno, mientras que $\mathrm{Zn}$ y $\mathrm{Cu}$ son dos de los elementos que no presentan interferencias por efecto de la matriz. Los resultados obtenidos de la aplicación de los cuatro diferentes métodos de digestión descritos anteriormente se muestran en la tabla 1.

Table 1. Metal concentrations in the coral samples for each digestion method used $\left(\mu \mathrm{g} \mathrm{g}^{-1}\right)$.

Tabla 1. Concentraciones metálicas de las muestras de corales $\left(\mu \mathrm{g} \mathrm{g}^{-1}\right)$ para cada método de digestión utilizado.

\begin{tabular}{ccccc}
\hline & \multicolumn{4}{c}{ Method } \\
\cline { 2 - 5 } Metal & $\begin{array}{c}\text { Digestion I } \\
8 \text { mol L}^{-1} \mathrm{HNO}_{3}\end{array}$ & $\begin{array}{c}\text { Digestion II } \\
\mathrm{HNO}_{3}: \mathrm{HCl}\end{array}$ & $\begin{array}{c}\text { Digestion III } \\
\mathrm{HNO}_{3}\end{array}$ & $\begin{array}{c}\text { Digestion IV } \\
\mathrm{HNO}_{3}: \mathrm{HClO}_{4}\end{array}$ \\
\hline $\mathrm{Fe}$ & $2.6 \pm 0.5$ & $4.6 \pm 1.3$ & $5.9 \pm 0.6$ & $13.9 \pm 0.7$ \\
$\mathrm{Cu}$ & $2.3 \pm 0.3$ & $5.3 \pm 0.1$ & $5.2 \pm 0.5$ & $5.6 \pm 0.1$ \\
$\mathrm{Zn}$ & $0.47 \pm 0.01$ & $1.05 \pm 0.14$ & $0.83 \pm 0.09$ & $4.4 \pm 0.7$ \\
\hline
\end{tabular}


were studied, over the recovery of the metal concentrations obtained .

In the mixture $\mathrm{HNO}_{3}: \mathrm{HClO}_{4}$ we have decided to maintain and fix $2 \mathrm{~mL}$ of $\mathrm{HClO}_{4}$, because it is considered as the minimal quantity used to digest the organic matter that could be present in the calcareous skeleton of the coral (González, 1989) and in this way, modifying the relationship of the mixture in function of the volume of $\mathrm{HNO}_{3}$.

The mathematical model was described as a linear function $(Y)$ of two independent variables: $Z_{1}$ and $Z_{2}$, where $Z_{1}$ is the $\mathrm{HNO}_{3}$ volume in the initial mixture of $\mathrm{HNO}_{3}$ and $\mathrm{HClO}_{4}, Z_{2}$ is the $\mathrm{HNO}_{3}$ volume added in the second step and $Y$ is the metal concentration $\left(\mu \mathrm{g} \mathrm{g}^{-1}\right)$ (fig. 1).

The factorial space chosen was designed based on the center of the plane. Optimization of the digestion IV procedure aimed (1) to extract the actual and greatest quantity of metal in the sample and (2) to minimize the quantities of acid used.

The mathematical model that describes factorial designs $2^{2}$ is a linear model:

$$
Y=b_{0}+b_{1} X_{1}+b_{2} X_{2}+b_{12} X_{1} X_{2}
$$

where $X_{1}$ and $X_{2}$ are the codified variables $Z_{1}$ and $Z_{2}$ for this study.

In table 2 are shown the conditions of the experiments, as well as the results of those for each element studied $(\mathrm{Fe}, \mathrm{Cu}$, $\mathrm{Zn})$. In all cases, the experiments were done by triplicate with three determinations for each replicate with total nine determinations in parallel.

After checking the reproducibility of the experiments, the coefficients of the model proposed for each metal were calculated using the software Statistica (1997). A Fisher's Significance Test was applied for each coefficient calculated in which the variance of the whole design and the variances of

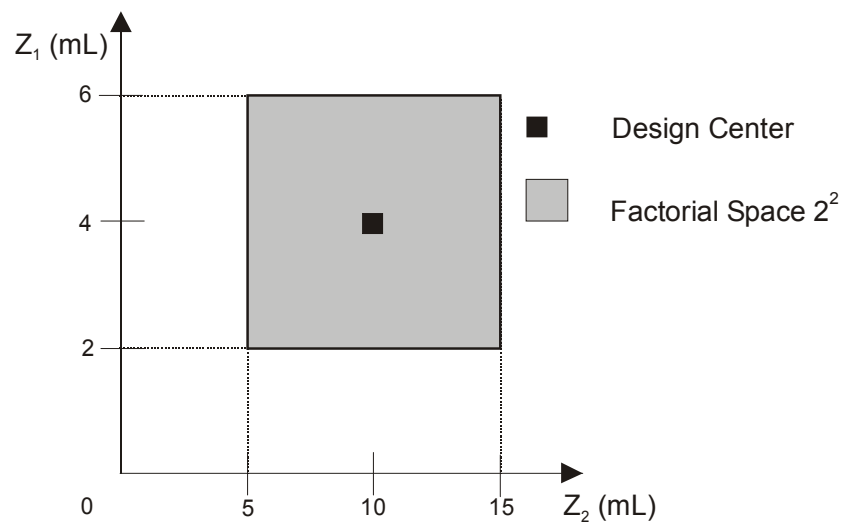

Figure 1. Representation of the actual physical coordinates of the design. Figura 1. Representación de las coordenadas físicas reales del diseño.
A partir de estos resultados aplicamos la prueba de hipótesis de comparación de medias, basada en el criterio $t$-Student, donde la hipótesis nula $\left[\mathrm{H}_{0}\right]: \bar{x}_{1} \neq \bar{x}_{2}$, consistió en comprobar la existencia o no de diferencias significativas entre los valores de concentración obtenidos en los diferentes tratamientos y como hipótesis alternativa $\left[\mathrm{H}_{1}\right]:$ si $\bar{x}_{1} \neq \bar{x}_{2}$ y $\bar{x}_{1}>\bar{x}_{2}$ entonces $\bar{x}_{1}$ es el valor aceptado como verdadero y el método utilizado es el procedimiento capaz de extraer la mayor concentración de la matriz coralina.

A partir de la aplicación de la prueba $t$-Student se concluye que existen diferencias significativas entre las digestiones utilizadas para un nivel de confianza de $95 \%$, y que el método de digestión IV, basado en el empleo de $\mathrm{HNO}_{3}: \mathrm{HClO}_{4}$ resultó ser el procedimiento de mayor efectividad en la disolución de la muestra.

\section{Diseño Experimental $2^{2}$}

Con objeto de caracterizar los parámetros que definen el método de digestión IV, seleccionado como el más efectivo, se aplicó un diseño de experimento $2^{2}$ para obtener un modelo matemático de este proceso de disolución, en una zona determinada por un espacio factorial.

En nuestro sistema se estudió la influencia de diferentes mezclas sinérgicas de $\mathrm{HNO}_{3}: \mathrm{HClO}_{4}$ y del volumen de $\mathrm{HNO}_{3}$ adicionado en la segunda etapa, sobre el rendimiento de las concentraciones de metal obtenidas.

En la mezcla $\mathrm{HNO}_{3}: \mathrm{HClO}_{4}$ se decidió fijar el $\mathrm{HClO}_{4}$ en 2 $\mathrm{mL}$ debido a que ésta se consideró la cantidad mínima necesaria para atacar la materia orgánica presente en el exoesqueleto calcáreo del coral (González, 1989), por lo que la proporción de la mezcla se modificó en función del volumen de $\mathrm{HNO}_{3}$.

El modelo matemático se describió como una función lineal $(Y)$ de dos variables independientes: $Z_{1}$ y $Z_{2}$, donde $Z_{1}$ es el volumen de $\mathrm{HNO}_{3}$ en la mezcla inicial de $\mathrm{HNO}_{3}$ y $\mathrm{HClO}_{4}, Z_{2}$ es el volumen de $\mathrm{HNO}_{3}$ adicionado en la segunda etapa, e $Y$ es la concentración metálica obtenida ( $\left.\mu \mathrm{g} \mathrm{g}^{-1}\right)$ (fig. 1).

El espacio factorial escogido se diseñó sobre la base del centro del plano. La optimización del método de digestión IV se basó en: (1) extraer la verdadera y mayor cantidad de metal de la muestra y (2) economizar y minimizar las cantidades de ácido utilizadas.

El modelo matemático que describe los diseños factoriales $2^{2}$ es un modelo lineal:

$$
Y=b_{0}+b_{1} X_{1}+b_{2} X_{2}+b_{12} X_{1} X_{2},
$$

donde $X_{1}$ y $X_{2}$ son las variables codificadas, $Z_{1}$ y $Z_{2}$, del sistema en estudio.

En la tabla 2 se muestran las condiciones de realización de los experimentos, así como los resultados de éstos para cada elemento en estudio ( $\mathrm{Fe}, \mathrm{Cu}, \mathrm{Zn}$ ). En todos los casos se realizó el experimento por triplicado, con tres determinaciones para cada réplica, con un total de nueve determinaciones paralelas. 
Table 2. Results of the $2^{2}$ experimental design.

Tabla 2. Resultados del diseño experimental $2^{2}$.

\begin{tabular}{|c|c|c|c|c|c|c|c|}
\hline & \multicolumn{7}{|c|}{ Iron $(\mathrm{Fe})$} \\
\hline & $Z_{1}$ & $Z_{2}$ & $X_{1}$ & $X_{2}$ & $X_{1} X_{2}$ & $Y$ & $S$ \\
\hline 1 & $6: 2$ & 5 & 1 & -1 & -1 & 10.6 & 1.3 \\
\hline 2 & $2: 2$ & 5 & -1 & -1 & 1 & 12.2 & 2.4 \\
\hline 3 & $6: 2$ & 15 & 1 & 1 & 1 & 11.4 & 1.6 \\
\hline 4 & $2: 2$ & 15 & -1 & 1 & -1 & 12.2 & 1.4 \\
\hline \multicolumn{8}{|c|}{ Copper $(\mathrm{Cu})$} \\
\hline & $Z_{1}$ & $Z_{2}$ & $X_{1}$ & $X_{2}$ & $X_{1} X_{2}$ & $Y$ & $S$ \\
\hline 1 & $6: 2$ & 5 & 1 & -1 & -1 & 4.5 & 0.5 \\
\hline 2 & $2: 2$ & 5 & -1 & -1 & 1 & 4.8 & 0.9 \\
\hline 3 & $6: 2$ & 15 & 1 & 1 & 1 & 4.6 & 0.5 \\
\hline 4 & $2: 2$ & 15 & -1 & 1 & -1 & 4.8 & 0.5 \\
\hline \multicolumn{8}{|c|}{ Zinc (Zn) } \\
\hline & $Z_{1}$ & $Z_{2}$ & $X_{1}$ & $X_{2}$ & $X_{1} X_{2}$ & $Y$ & $S$ \\
\hline 1 & $6: 2$ & 5 & 1 & -1 & -1 & 3.5 & 0.8 \\
\hline 2 & $2: 2$ & 5 & -1 & -1 & 1 & 3.4 & 0.4 \\
\hline 3 & $6: 2$ & 15 & 1 & 1 & 1 & 3.6 & 0.8 \\
\hline 4 & $2: 2$ & 15 & -1 & 1 & -1 & 3.8 & 0.5 \\
\hline
\end{tabular}

each coefficient were compared, as well as the adequate fitting of the model (table 3).

From the results in table 3 , the mathematical model is reduced to a constant function, $Y=b_{0}$, for all cases. So, when the suitability of the regression equation is verified, it is possible to establish that the equation obtained properly describes the experimental results for $\alpha=0.05$ and, threrefore it can be used in around the factorial space in which the experiments were carried out.

In any point of the factorial space the metal concentration is constant, then optimization is achieved without affecting the quality of the results, by taking as optimum digestion that in the factorial space with the lowest coordinate values both for $Z_{1}\left(\mathrm{HNO}_{3}\right.$ volume in the $\mathrm{HNO}_{3}: \mathrm{HClO}_{4}$ mixture) and for $Z_{2}$ $\left(\mathrm{HNO}_{3}\right.$ volume added in the second step) (fig. 2).
Después de comprobada la reproducibilidad de los experimentos se calcularon los coeficientes del modelo propuesto para cada metal, utilizando el software Statistica (1997). Para cada coeficiente calculado se aplica un Test de Significación del tipo Fisher, donde se comparan la varianza del diseño completo y las varianzas de cada coeficiente, así como los test de adecuación del modelo (tabla 3).

A partir de los resultados de la tabla 3, el modelo matemático se reduce a una función constante, $Y=b_{0}$, para todos los casos. Al verificar el ajuste de la ecuación de regresión se puede establecer que la ecuación obtenida describe adecuadamente los resultados experimentales para $\alpha=0.05$ y puede, por tanto, ser utilizada en las inmediaciones del espacio factorial en que fueron realizados los experimentos.

En cualquier punto del espacio factorial estudiado la concentración de metal es constante por lo que se puede optimizar el método de digestión, sin afectar la calidad de los resultados, tomando como digestión óptima aquella dentro del espacio factorial que corresponde a los menores valores de las coordenadas, tanto para $Z_{1}$ (volumen de $\mathrm{HNO}_{3}$ en la mezcla $\mathrm{HNO}_{3}: \mathrm{HClO}_{4}$ ) como para $Z_{2}$ (volumen de $\mathrm{HNO}_{3}$ adicionado en la segunda etapa) (fig. 2).

Prueba de exactitud

La prueba de exactitud de un método está directamente relacionada con los sistemas de validación de sus procedimientos analíticos ya que la exactitud o sesgo relaciona la concordancia entre la concentración medida y la concentración real o conocida como verdadera (Valcárcel y Ríos, 1992). Los orígenes del sesgo radican en los errores aleatorios y sistemáticos que tienen lugar durante la preparación de las muestras, así como de los errores operacionales e instrumentales.

Existen tres formas para validar un procedimiento analítico $y$, por tanto, para evaluar la exactitud de la metodología establecida: el análisis de material de referencia certificado, las pruebas de recuperación/dilución y la comparación respecto a resultados obtenidos por otros métodos validados.

Con el objetivo de validar el procedimiento de digestión de la muestra propuesto como digestión IV, se optó por el análsis de un material de referencia certificado, ya que este sistema se considera la mejor forma de estimar la exactitud. Dado que no se dispone actualmente de materiales de referencia certificados

Table 3. Results of the regression equation parameters.

Tabla 3. Resultados de los parámetros de la ecuación de regresión.

\begin{tabular}{ccccccc}
\hline \multirow{2}{*}{ Coefficient } & \multicolumn{2}{c}{$\mathrm{Fe}$} & \multicolumn{2}{c}{$\mathrm{Cu}$} & \multicolumn{2}{c}{$\mathrm{Zn}$} \\
\cline { 2 - 6 } & Value & Test & Value & Test & Value & Test \\
\hline$b_{0}$ & 11.6 & accepted & 4.6 & accepted & 3.6 & accepted \\
$b_{1}$ & -0.6 & rejected & -0.1 & rejected & -0.01 & rejected \\
$b_{2}$ & 0.2 & rejected & 0.03 & rejected & 0.1 & rejected \\
$b_{12}$ & 0.2 & rejected & 0.03 & rejected & -0.1 & rejected \\
\hline
\end{tabular}




\section{Accuracy test}

The accuracy test of a method is directly related to the validation methods of its analytical procedures, since the accuracy or bias is related to the concordance between the concentration measured and the actual or known concentration (Valcárcel and Ríos, 1992). The origins of the bias stem on the random and systematical errors that occur during the preparation of samples, as well as on the operational and instrumental errors.

There are three ways to validate an analytical procedure and therefore evaluate the accuracy of the methodology established: the analysis of certified reference material, the recovery/dilution tests, and the comparison with the results obtained by other validated methods.

Aiming to validate the proposed sample digestion procedure labeled as digestion IV, the analysis of a certified reference material was chosen, since it is considered the best way to evaluate accuracy. Since there are not currently certified reference materials for metal analysis in corals, we used for this validation the certified soil sample SOIL-7, a reference standard supplied by the OIEA (1985).

The selection of this standard was based on two fundamental criteria: (a) to use a material with a high $\mathrm{Ca}$ content $(17 \%)$, having an alkaline or alkaline-earthen matrix similar to that of the coral samples, and (b) to use a similar mineral structure, or perhaps a more complex one than that of the samples studied, since, if the digestion procedure selected is optimum for a soil reference sample, with a more complex mineral structure, this should also be adequate for a coral. para el análisis de metales pesados en corales, se decidió utilizar una muestra certificada de suelo para esta validación. Para ello se utilizó el patrón de referencia SOIL-7, suministrado por la OIEA (1985).

La elección de este suelo se realizó con base en dos criterios fundamentales: (a) utilizar un material con un elevado contenido de $\mathrm{Ca}(17 \%)$ con objeto de disponer de una matriz alcalino-térrea parecida a la de las muestras de corales, y (b) utilizar una estructura mineral parecida o quizás más compleja que las muestras objeto de estudio, ya que si la digestión es óptima para un suelo, con estructura mineral más compleja, ésta puede ser también adecuada para un coral.

La prueba de exactitud consistió en aplicar la metodología propuesta a la muestra de referencia siguiendo de manera estricta las recomendaciones del procedimiento y el diagrama de flujo analítico. Posteriormente los valores obtenidos fueron analizados según las recomendaciones del National Institute of Standard Tecnology (NIST,1992).

En la aplicación de la prueba, la ausencia de desviación sistemática requirió que la diferencia $(\Delta)$ entre la media de la mediciones $\left(\mu_{1}\right)$ y el valor verdadero o real $\left(\mu_{0}\right)$ fuera menor que el valor crítico de la desviación $\left(\Delta_{\mathrm{c}}\right)$, donde la diferencia entre el valor medido y el valor real o conocido como verdadero está dada por $\Delta=\left(\mu_{1}-\mu_{0}\right)$, y

$$
\Delta_{\mathrm{c}}=t_{1-\alpha / 2} \frac{S}{\sqrt{n}}+U
$$

es la diferencia crítica que tiene en cuenta $t_{1-\alpha / 2}$ para una distribución $t$-Student de dos colas; $\mathrm{S}$ es la desviación estándar

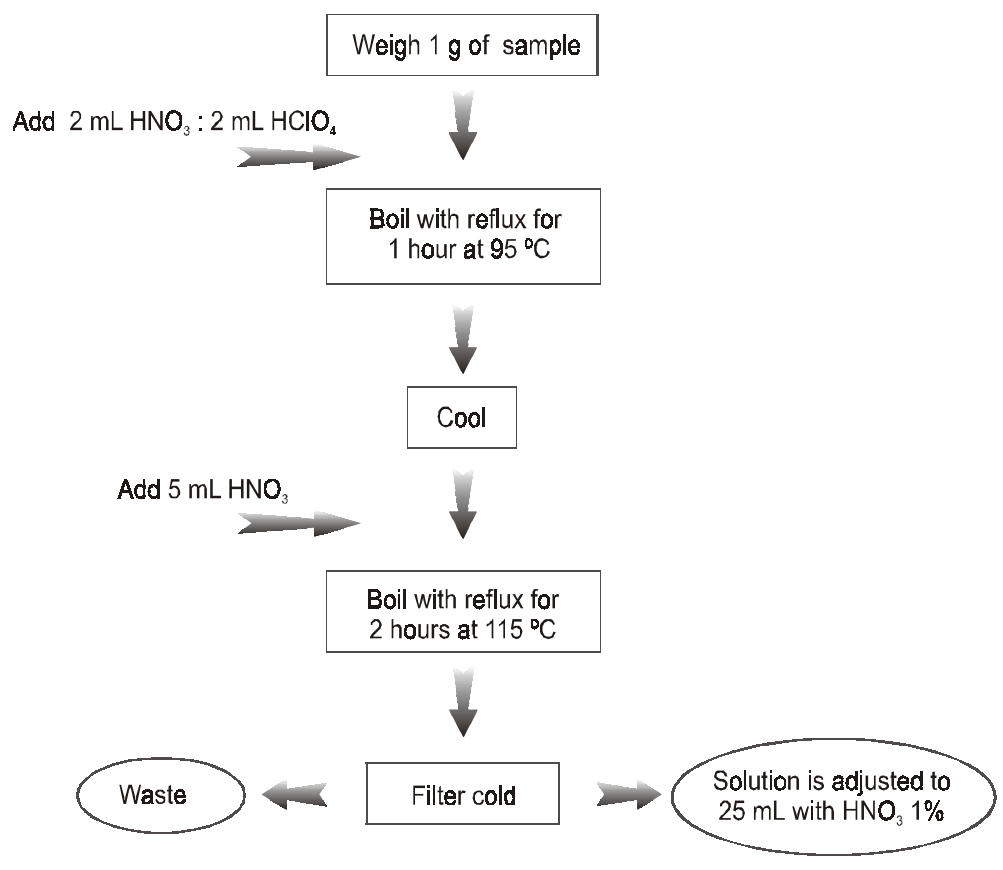

Figure 2. Flowchart for the optimal digestion method for scleractinian coral samples. Figura 2. Diagrama de flujo para la digestión óptima de corales escleractíneos. 
The accuracy test consisted on using the proposed methodology on the reference standard strictly following the recommendations of the procedure and the analytical flowchart. Then, these results were analyzed according to the recommendations of the National Institute of Standard Technology (NIST, 1992).

In the test, the absence of systematic deviation requires the difference $(\Delta)$ between the average of the measurements $\left(\mu_{1}\right)$ and the true or actual value $\left(\mu_{\mathrm{o}}\right)$ to be less than the critical value of deviation $\left(\Delta_{c}\right)$, where $\Delta=\left(\mu_{1}-\mu_{\mathrm{o}}\right)$ is the difference between the measured value and the actual value;

$$
\Delta_{\mathrm{c}}=t_{1-\alpha / 2} \frac{S}{\sqrt{n}}+U
$$

is the critical difference considering $t_{1-\alpha / 2}$, a two-tailed $t$ Student distribution; $\mathrm{S}$ is the standard deviation of the measurements; $n$ is the number of repetitions; $U$ are the uncertainty levels assigned to the actual values, which are assumed symmetrical.

When $\Delta<\Delta_{\mathrm{c}}$ the test is positive, therefore validating the results of the method validates granting its trazability and quality.

For this case we prepared 10 replicates and the simultaneous preparation of two blanks. The results of this test are shown in table 4.

According to the results obtained in the test, no systematical errors in respect to the certified values were detected, so the mean value of the measurements was accepted as real.

\section{Application of the methodology}

Once the optimum sample digestion methodology was established, it was applied to five kinds of corals. The results obtained are shown in table 5. Also, a transversal analysis of Dichocoenia stokesi and Porites astreoides was accomplished, dividing up the colony in three parts: the lower part (attached to marine floor and close to the sediment), the middle part and the upper part (the most recent superficial part and close to water).

Results in table 5 show the following conclusions: in general, the increasing order of metal concentrations is $\mathrm{Ca}>\mathrm{Fe}$ $>\mathrm{Zn}>\mathrm{Mn}>\mathrm{Cu}>\mathrm{Ni}$, except for $\mathrm{Cu}$ in Colpophyllia natans with an outstanding value, $D$. stokesi and $P$. astreoides showed de las mediciones; $n$ el número de repeticiones; y $U$ las cotas de incertidumbre asignadas a los valores reales, los cuales se suponen simétricos.

Cuando $\Delta<\Delta_{\mathrm{c}}$ el test es positivo y el método valida los resultados y, por tanto, se garantiza su trazabilidad y calidad.

Para este caso se prepararon 10 réplicas, además de la preparación simultánea de dos blancos. En la tabla 4 se muestran los resultados de esta prueba.

Según los resultados obtenidos en el test de exactitud, se concluye que no se detectan errores sistemáticos respecto al valor certificado, por lo que el valor de la media de las mediciones se acepta como verdadero.

Aplicación de la metodología

Una vez determinada la metodología óptima de digestión de la muestra, ésta se aplicó a cinco especies de corales. Los resultados obtenidos se muestran en la tabla 5. Además, a las especies Dichocoenia stokesi y Porites astreoides se les realizó un análisis transversal, dividiendo la colonia en tres partes: la parte inferior (unida al lecho marino y en contacto con el sedimento), la parte media y la parte superior (parte superficial más reciente y en contacto con el agua).

De los resultados de la tabla 5 se pueden obtener las siguientes conclusiones: de forma general, en todos los corales el orden creciente de las concentraciones metálicas es $\mathrm{Ca}>\mathrm{Fe}$ $>\mathrm{Zn}>\mathrm{Mn}>\mathrm{Cu}>\mathrm{Ni}$, excepto para el $\mathrm{Cu}$ en Colpophyllia natans con un valor bastante elevado; $D$. stokesi y $P$. astreoides tuvieron valores más altos debido a la forma compacta de sus colonias y a su mayor área superficial. Para las diferentes partes de los corales seccionados, los valores de concentración más altos correspondieron a la parte inferior, cercana al sedimento, el cual tiene una mayor influencia sobre los niveles metálicos en los corales; solamente el Ni mostró un mayor valor en la parte media, probablemente debido a una mayor influencia de la concentración de este metal en el agua, y al metabolismo del mismo en el propio coral.

\section{Conclusiones}

Se establecieron las condiciones óptimas de digestión para el análisis de metales pesados en muestras de corales por EAA, según el diagrama de flujo de la figura 2, empleando un procedimiento muy simple. Entre los métodos comunes evaluados, el método de digestión y disolución de la muestra basado en el empleo de $\mathrm{HNO}_{3}$ y $\mathrm{HClO}_{4}$ resultó ser el de mayor exactitud en

Table 4. Accuracy test for the optimum digestion method, applied to reference material SOIL-7 (OIEA, 1985).

Tabla 4. Prueba de exactitud para el método de digestión óptimo, aplicado a la muestra de referencia SOIL-7 (OIEA, 1985).

\begin{tabular}{lrrrrrrrr}
\hline Metal & \multicolumn{1}{c}{$\mu_{0}$} & $U$ & $n$ & $\mu_{1}$ & $S$ & $\Delta$ & $\Delta_{\mathrm{c}}$ & Test $\left(t_{1-\alpha / 2}\right)$ \\
\hline $\mathrm{Fe}$ & 25700 & 550 & 10 & 25608 & 131 & 92 & 643 & accepted \\
$\mathrm{Zn}$ & 104 & 6 & 10 & 109 & 1 & 5 & 6.5 & accepted \\
$\mathrm{Cu}$ & 11 & 2 & 10 & 9 & 1 & 2 & 2.3 & accepted \\
\hline
\end{tabular}


Table 5. Metal concentrations $\left(\mu \mathrm{g} \mathrm{g}^{-1}\right)$ in scleractinian corals of the Cuban insular platform.

Tabla 5. Concentraciones metálicas $\left(\mu \mathrm{g} \mathrm{g}^{-1}\right)$ en corales escleractíneos de la plataforma insular cubana.

\begin{tabular}{lcccccc}
\hline \multicolumn{1}{c}{ Coral } & $\mathrm{Cu}$ & $\mathrm{Mn}$ & $\mathrm{Ni}$ & $\mathrm{Zn}$ & $\mathrm{Fe}$ & $\mathrm{Ca}(\%)$ \\
\hline Colpophyllia natans & $5.7(11)$ & $0.9(6)$ & $0.4(6)$ & $4.4(7)$ & $13.9(5)$ & $34.5(3)$ \\
Mycetophyllia lamarckiana & $1.1(5)$ & $5.4(16)$ & $1.2(12)$ & $13.3(11)$ & $60.9(0.5)$ & $32.9(6)$ \\
Porites porites & $1.1(5)$ & $1.7(16)$ & $0.6(10)$ & $13.2(12)$ & $50.5(5)$ & $38.4(3)$ \\
Dichocoenia stokesi & & & & & & $35.2(3)$ \\
Superior & $1.9(2)$ & $2.6(13)$ & $<0.02$ & $5(12)$ & $34.9(2)$ & \\
Center & $1.9(9)$ & $3.3(9)$ & $1.2(5)$ & $10.4(4)$ & $44.4(9)$ & \\
Inferior & $2.6(1)$ & $19.1(3)$ & $0.4(8)$ & $30.3(2)$ & $101(0.6)$ & \\
Porites astreoides & & & & & & $37.6(3)$ \\
$\quad$ Superior & $1.3(2)$ & $1.4(11)$ & $<0.02$ & $8.4(1)$ & $31.3(3)$ & \\
Center & $1(10)$ & $2.5(12)$ & $1.5(8)$ & $15.7(1)$ & $65.4(3)$ & \\
Inferior & $1.9(2)$ & $3.5(8)$ & $0.6(10)$ & $26.5(3)$ & $80.1(3)$ & \\
\hline
\end{tabular}

(C.C. \%) - Variation Coefficient for each sample (3 replicates).

Note: The concentrations of Ca were analyzed by complexometry with EDTA (APHA, 1998).

higher values owing to the compact form of their colonies and their greater superficial area. For the sectioned corals, the higher concentrations were obtained in the lower part, near the sediment that produces higher influence on the metal levels of these corals; only Ni showed higher concentration in the middle part, probably influenced by its concentration in the water and the metabolism of this metal in the coral.

\section{Conclusions}

We have established the optimum digestion conditions for heavy metal analysis in coral samples by AAS, according to the flowchart in figure 2 , using a simple procedure. The digestion and dissolution method of the sample based on the use of $\mathrm{HNO}_{3}$ and $\mathrm{HClO}_{4}$ turned out to be the most reliable in the analysis among the common methods evaluated. The results obtained about the efficiency of the optimum digestion are assured by the accuracy test and so the quality of the analytical results based on the application of this methodology is guaranteed.

\section{References}

American Public Health Association (1998). Standard Methods for Examination of Water and Waste Water, 17 ed., City Press, Baltimore, $786 \mathrm{pp}$.

Babxel, Arcal IV (1995). rla/002/3.

Barnes, D.J. and Chalker, B.E. (1990) Calcification and photosynthesis in reef-building corals and algae. In: Z. Dubinsky (ed.), Coral Reefs. Elsevier, Amsterdam, pp. 109-131.

Brown, B.E. (1987). Fate of metals in biota and biological interactions in the tropical coastal zone. In: U. Seelinger, L.D. de Lacerta et al. (eds.) Metals in Coastal Environments of Latin America. Singer-Vertag, $297 \mathrm{pp}$. el análisis. Los resultados obtenidos acerca de la eficacia de la digestión óptima están asegurados por la prueba de exactitud y de esta forma se garantiza la calidad de los resultados analíticos basados en la aplicación de esta metodología.

Traducido al español por los autores.

Carmody, D.J. et al. (1983). Chemical methods for use in marine monitoring. UNESCO 12, report, $53 \mathrm{pp}$.

D'Elia, C.F., Burddemeier, R.W. and Smith, S.V. (1991). Work-shop on coral bleaching, coral reef ecosystems and global change: report or proceedings. Maryland Sea Grant College publication number UM-SG-TS-91-03, University of Maryland, College Park, $49 \mathrm{pp}$.

Denton, G.R.W. and Burdon-Jones, C. (1986). Trace metals in corals from the Great Barrier Reef. Mar. Poll. Bull., 17(5): 209-213.

Esslemont, G. (1997). Heavy metals in scleractinian corals and marine sediments from Darwin Harbour, Australia. In: J.R. Hanley, G. Caswell, G. Megirian and H.K. Larson (eds.), Proceedings of the Sixth International Marine Biological Workshop. The Marine Flora and Fauna of Darwin Harbour. Northern Territory, Australia, Museums and Art Galleries of the Northern Territory, Darwin. pp. 399-410.

Glynn, P.W. (1989). Condition of coral reef cnidarians from the Northern Florida Reef Tract. Mar. Poll. Bull., 20(11): 568-576.

Gómez, M. et al. (1995). Preparación de muestras de corales escleractíneos para análisis espectrométricos, Reporte de Investigación, Instituto de Oceanología, Cuba.

González, H. (1989). Estudio de la contaminación marina por metales pesados en algunas áreas cubanas. Tesis de Doctorado, Revista CENIC, Cuba.

Hanna, R.G. and Muir, G.L. (1990) Red Sea coral as biomonitors of trace metals pollution. Environ. Monit. Asses., 14: 211-222.

Howrad, L.S. and Brown, B.E. (1984). Heavy metals and reef corals. Ocean. Mar. Biol. Ann. Rev., 22: 195-210. 
Linn, L.J., Delaney, M.L. and Druffel, E.R.M. (1990). Trace metals in contemporary and seventeenth century Galapagos coral-records of seasonal and annual variations. Geochim. Cosmochim. Acta, 54: 387-394.

Luoma, S.N. (1990). Processes affecting metal concentrations in estuarine and coastal marine sediments. In: R.W. Furness and P.S. Rainbow (eds.), Heavy Metals in the Marine Environment, CRC Press, Boca Raton, Florida pp. 51-66.

Martínez, N., Martínez, M. et al. (1989). Metales pesados en corales escleractíneos de la plataforma marina de Moa-Cuba. Reporte de Investigación, Instituto de Oceanología, Cuba.

NIST (1992). Use of NIST standard reference materials for decision on performance of analytical chemical methods and laboratories. USA Commerce Department's Technology Administration. Special Publication 829.

OIEA $(1985,1987)$ Intercalibration of Analytical Methods on Marine Environmental Samples. Trace Element Measurements on Shrimp Homogenate. Results of the Worldwide Intercomparison Run MA-A-3/TM and of the MEDPOL Exercise MA (S) MED 86//M. Laboratory of Marine Radioactivity, Monaco. Reps. no. 24 and 26 (1985), and 34 (1987).
Páez-Osuna, F. and Ruiz-Fernandez, A.C. (1995). Comparative bioaccumulation of trace metals in Penaeus stylirostris in estuarine and coastal environments. Estuar. Coast. Shelf Sci., 40: $35-44$.

Price, W.J. (1979). Spectrochemical Analysis by Atomic Absorption, Heyden and Son Ltd., Belgium, 238 pp.

Schneider, R.C. and Smith, S.V. (1982). Skeletal Sr content and density in Porites porites in relation to environmental factors. Mar. Biol., 66: 121-130.

Shen, G.T., Boyle, E.A. and Lea, D.W. (1987). Cadmium in corals as a tracer of historical upwelling and industrial fallout. Nature, 328: 794-796.

Shen, G.T. and Boyle, E.A. (1988) Determination of lead, cadmium and other trace metals in annually-banded corals. Chem. Geol., 67: 47-62.

StatSoft (1997). Statistica 6.0 for Windows. Release 5.1, Copyright 1984-1998. StatSoft Inc.

Varcárcel, M. and Ríos, A. (1992). La Calidad en los Laboratorios Analíticos. Editorial Reverté, S.A., España, 426 pp. 